Environment and Development Economics 21: 626-648 (C) Cambridge University Press 2016 This is an Open Access article, distributed under the terms of the Creative Commons Attribution licence (http://creativecommons.org/licenses/by/4.0/), which permits unrestricted re-use, distribution, and reproduction in any medium, provided the original work is properly cited.

doi:10.1017/S1355770X16000061

\title{
Water utilization and water quality in endogenous economic growth
}

\author{
SOUHA EL KHANJI \\ Department of Economics, University of Bath, Bath, BA2 7AY, United \\ Kingdom. \\ Email: souha.el-khanji@bath.edu
}

\section{JOHN HUDSON}

Department of Economics, University of Bath, United Kingdom. Email: j.r.hudson@bath.ac.uk

Submitted 28 September 2014; revised 31 October 2015; accepted 23 January 2016; first published online 18 April 2016

\begin{abstract}
Our study examines the effect of water utilization together with the effect of water quality on economic growth across countries. We constructed a panel of 177 countries covering the period of 1960-2009. We analyse two dependent variables, gross domestic product per capita and the average of five years of growth. The analysis is conducted using a fixed effects model and fixed effects with instrumental variables. We find that although water utilization affects growth, water quality also proves to be highly significant and affects growth in both the short and long run to a greater degree than water quantity.
\end{abstract}

\section{Introduction}

The realization that water has an impact on economic growth has triggered the need to emphasize and understand the nature of this impact. The Pacific Institute (2007) concludes that the scarcity of fresh water is 'already an economic constraint in major growth markets such as China, India, and Indonesia, as well as commercial centres in Australia and the western United States' (Pacific Institute, 2007: 5). According to the estimates, China and the Asian developed countries need US\$38.2 to US\$51.4 billion a year for water supply and wastewater treatment (WWAP, 2009). The same report, the third United Nations World Water Development Report, also specifies the direct economic benefits of investments in water systems, especially in developing countries where water shortages are hampering economic growth.

We would like to thank the two anonymous reviewers for their helpful comments. 
Population and economic growth increase the stress on water resources. Water resources are finite but the demand for them cannot be considered as finite. We cannot exclude the deterioration of natural resources and pollution when we discuss the effect of water withdrawal on economic growth. Human activities, including urbanization and industrialization, place added stress on finite water resources, which water pollution exacerbates. How can societies both sustain their environment and guarantee long-term economic growth? The benefits from economic growth are accompanied by environmental degradation. However, the statistics reflect a relation between high income per capita and high levels of water consumption. The data in table 1 reflect the fact that water resource availability, or lack of it, is linked to economic and social progress as represented by gross domestic product (GDP) per capita. This suggests that development is likely to be influenced by how water resources are managed. The table emphasizes that as countries get richer, they tend to become more intensive users of water - particularly for non-agricultural purposes. According to Sullivan (2002), if there is water poverty, any measures to reduce income poverty are unlikely to be successful.

Previous research, in particular by Barbier (2004), has found that water usage has an impact on economic growth. This was based on a limited data set, and Barbier himself called for further analysis. But there has been very little further analysis of the impact of water quality on growth. Yet we would expect such a link for a number of reasons. First, there is reason to suppose that entrepreneurs - and this may include those linked to foreign direct investment (FDI) - partially base their choice of location on the quality of life. Abundant water may enhance the quality of life, but environmental pollution reduces it and may thus reduce growth. Second, water is an input in the production process, but polluted water may be less efficient in this aspect as it may require some form of treatment before use.

We should emphasize that the focus is on growth, but we also examine the linkages with GDP per capita, which is dependent on resources and how efficiently these are being used at any one point in time. We anticipate that there may well be differences in the impact of the environmental variables on GDP per capita and its rate of growth. Thus Fracasso (2014) found evidence that countries that have scarce water resources find it hard to export virtual water and tend to import water services embodied in agricultural goods. To the extent that this is a constraint on economic activity, we might expect scarce water to impact GDP per capita but not necessarily growth.

The paper proceeds as follows: in section 2 we will describe the model and then introduce the estimation framework; section 3 will present the empirical results; finally we conclude the paper.

\section{Description of the model}

2.1. Theoretical background

When modelling a renewable natural resource in an endogenous growth model, we find a substantial literature dealing with limited natural 
Table 1. Water use and national income

\begin{tabular}{|c|c|c|c|c|c|c|c|}
\hline Country Name & Time & $\begin{array}{c}\text { GDP per } \\
\text { capita (constant } \\
2005 \text { US\$) }\end{array}$ & $\begin{array}{c}\text { Agricultural (\% of } \\
\text { total freshwater } \\
\text { withdrawal) }\end{array}$ & $\begin{array}{l}\text { Industrial (\% of } \\
\text { total freshwater } \\
\text { withdrawal) }\end{array}$ & $\begin{array}{l}\text { Domestic (\% of } \\
\text { total freshwater } \\
\text { withdrawal) }\end{array}$ & $\begin{array}{l}\text { Total annual } \\
\text { freshwater } \\
\text { withdrawals } \\
\left(\text { billion } \mathrm{m}^{3} \text { ) }\right.\end{array}$ & $\begin{array}{c}\text { Total annual } \\
\text { freshwater } \\
\text { withdrawals (\% of } \\
\text { internal resources) }\end{array}$ \\
\hline \multicolumn{8}{|c|}{ Sub-Saharan Africa region } \\
\hline \multirow[t]{2}{*}{ Angola } & 2002 & 1374.253 & 32.79 & 28.81 & 38.41 & 0.6405 & 0.43277027 \\
\hline & 2013 & 2737.877 & 20.78 & 33.95 & 45.27 & 0.7058 & 0.47689189 \\
\hline \multirow[t]{2}{*}{ Burundi } & 1987 & 217.470 & 64 & 0 & 36 & 0.1 & 0.994 \\
\hline & 2013 & 150.74 & 77.08 & 5.903 & 17.01 & 0.288 & 2.86 \\
\hline \multirow[t]{2}{*}{ Chad } & 1987 & 387.89 & 81.77 & 2.21 & 16.02 & 0.181 & 1.21 \\
\hline & 2013 & 738.22 & 76.42 & 11.79 & 11.79 & 0.8796 & 5.86 \\
\hline \multirow[t]{2}{*}{ Congo, Dem. Rep. } & 2002 & 196.25 & 12.31 & 21.04 & 66.65 & 0.5841 & 0.06 \\
\hline & 2007 & 223.78 & 10.52 & 21.47 & 68.01 & 0.6836 & 0.08 \\
\hline \multirow[t]{2}{*}{ Kenya } & 1992 & 523.46 & 76.43 & 3.904 & 19.67 & 2.049 & 9.90 \\
\hline & 2013 & 642.14 & 79.16 & 3.656 & 17.18 & 2.735 & 13.21 \\
\hline \multirow{2}{*}{ South Africa } & 1992 & $4,709.78$ & 71.98 & 10.88 & 17.14 & 13.31 & 29.71 \\
\hline & 2013 & $6,090.27$ & 62.69 & 6.048 & 31.23 & 12.5 & 27.90 \\
\hline \multicolumn{8}{|c|}{ Middle East and North Africa region } \\
\hline \multirow[t]{2}{*}{ Algeria } & 1992 & $2,470.57$ & 60 & 15.11 & 24.89 & 4.5 & 40.00 \\
\hline & 2013 & $3,330.80$ & 61.19 & 14.58 & 24.24 & 5.723 & 50.87 \\
\hline \multirow[t]{2}{*}{ Egypt, Arab Rep. } & 1997 & $1,001.13$ & 86.14 & 7.523 & 6.334 & 58.87 & $3,270.56$ \\
\hline & 2013 & $1,467.61$ & 86.38 & 5.857 & 7.76 & 68.3 & $3,794.44$ \\
\hline
\end{tabular}


Table 1. Continued

\begin{tabular}{|c|c|c|c|c|c|c|c|}
\hline Country Name & Time & $\begin{array}{c}\text { GDP per } \\
\text { capita (constant } \\
2005 \text { US\$) }\end{array}$ & $\begin{array}{c}\text { Agricultural (\% of } \\
\text { total freshwater } \\
\text { withdrawal) }\end{array}$ & $\begin{array}{l}\text { Industrial (\% of } \\
\text { total freshwater } \\
\text { withdrawal) }\end{array}$ & $\begin{array}{l}\text { Domestic (\% of } \\
\text { total freshwater } \\
\text { withdrawal) }\end{array}$ & $\begin{array}{l}\text { Total annual } \\
\text { freshwater } \\
\text { withdrawals } \\
\left(\text { billion } \mathrm{m}^{3}\right)\end{array}$ & $\begin{array}{c}\text { Total annual } \\
\text { freshwater } \\
\text { withdrawals (\% of } \\
\text { internal resources) }\end{array}$ \\
\hline \multirow[t]{2}{*}{ Iraq } & 1987 & $1,371.78$ & 97.51 & 0.4144 & 2.072 & 41.02 & 116.53 \\
\hline & 2013 & $2,644.70$ & 78.79 & 14.7 & 6.515 & 66 & 187.50 \\
\hline \multirow[t]{2}{*}{ Lebanon } & 1997 & $5,378.30$ & 67.67 & 3.867 & 28.46 & 1.293 & 26.94 \\
\hline & 2013 & $7,198.67$ & 59.54 & 11.45 & 29.01 & 1.31 & 27.29 \\
\hline \multirow[t]{2}{*}{ Qatar } & 2002 & $52,927.47$ & 71.45 & 4.729 & 23.82 & 0.2939 & 524.82 \\
\hline & 2013 & $61,814.09$ & 59.01 & 1.802 & 39.19 & 0.444 & 792.86 \\
\hline \multicolumn{8}{|c|}{ South American region } \\
\hline \multirow{2}{*}{ Bolivia } & 1987 & 784.11 & 85 & 5 & 10 & 1.24 & 0.41 \\
\hline & 2013 & $1,357.63$ & 91.95 & 1.533 & 6.513 & 2.088 & 0.69 \\
\hline \multirow[t]{2}{*}{ Brazil } & 1997 & $4,383.01$ & 60.93 & 18.12 & 20.96 & 54.87 & 0.97 \\
\hline & 2013 & $5,896.10$ & 60 & 17 & 23 & 74.83 & 1.32 \\
\hline \multirow[t]{2}{*}{ Colombia } & 2002 & $3,076.08$ & 63.52 & 4.635 & 31.85 & 7.746 & 0.34 \\
\hline & 2013 & $4,497.20$ & 54.3 & 19.05 & 26.63 & 11.77 & 0.52 \\
\hline \multirow[t]{2}{*}{ Paraguay } & 1987 & $1,367.12$ & 78 & 7 & 15 & 0.43 & 0.46 \\
\hline & 2013 & $2,029.53$ & 78.62 & 6.382 & 15 & 2.413 & 2.06 \\
\hline \multirow[t]{2}{*}{ Venezuela, RB } & 2002 & $4,759.50$ & 43.8 & 7.536 & 48.67 & 9.064 & 1.13 \\
\hline & 2013 & $6,429.20$ & 73.84 & 3.506 & 22.64 & 22.63 & 2.81 \\
\hline
\end{tabular}

Source: World Bank Development indicators.

Notes: We find the correlation between the GDP per capita and the annual freshwater withdrawal $=0.2120, p$-values $<0.01$ (which suggests a relationship between water withdrawal and GDP per capita). 
resources in growth theory (for example Barbier, 1999; Chambers and Guo, 2009). Several contributions base their model on the AK model. The AK model incorporates the aggregate production $Y$ of the representative producer $i$ with capital $K$ that can be expressed as:

$$
Y_{i}=A K_{i}
$$

where $A$ is the marginal product of capital. Barbier (2004) considers water as a public non-excludable good subject to congestion. He introduced a basic model of growth that can be represented as:

$$
Y_{i}=A K_{i} f\left(\text { water withdrawal), where } f^{\prime}>0 \text { and } f^{\prime \prime}<0 .\right.
$$

Economists widely use the Cobb-Douglas model with natural resources to illustrate the diminishing returns of capital. Bretschger and Smulders (2007) also used the Cobb-Douglas framework to decouple growth from environmental degradation. We can use the Cobb-Douglas function as:

$$
Y=A K^{\alpha_{1}} L^{\alpha_{2}} W^{\alpha_{3}} P^{1-\alpha_{1}-\alpha_{2}-\alpha_{3}}
$$

where $W$ is the water resource, $K$ is the capital, $L$ is labour, $P$ is water pollution, $A$ is the total factor productivity and the production coefficients of the Cobb-Douglas production function are expressed as $\alpha_{i}$, with $i=1,2,3$ and the constraint $\sum \alpha_{i}=1$.

Assuming water is the only additional factor of production in the economy, and $S$ is the stock of a renewable natural resources, the dynamics of the renewable water resources can be represented by $\dot{S}=\eta_{S}(S)-W$, where $\eta_{S}(S)$ is the rate of water generation; if consumption is greater than this rate, then the stock $S$ declines and tends to reach zero, $S \rightarrow 0$. But if consumption is less than the generating stock, then the stock of water resources increases. Bretschger and Smulders (2007) commented on the concept in this model as it helps to illustrate the diminishing returns of capital and that there is a substitution between capital and pollution. The average productivity of capital per unit of output, together with the impact of extracted water and the pollution accompanying output, can be expressed as:

$$
\frac{Y}{K}=A\left(\frac{L}{K}\right)^{\alpha_{2}}\left(\frac{W}{K}\right)^{\alpha_{3}}\left(\frac{P}{K}\right)^{1-\alpha_{1}-\alpha_{2}-\alpha_{3}} \text { where } 0<\alpha_{1}, \alpha_{2}, \alpha_{3} .
$$

Owing to input substitution, the productivity of capital in the economy increases with water consumption, and is affected by pollution.

In our empirical model we are going to construct a linear model. The focus of the paper is on the empirical work rather than constructing a theoretical model. Nonetheless, the model does build on others in terms of the non-environmental variables we include. In the Romer-Stiglitz model of endogenous growth, resource scarcity and population growth determine the optimal level of 'balanced' growth for an economy. This endogenous growth literature has, in general, not been concerned with the contribution of natural resources to growth. However, Barbier (1999) builds onto this the possibility of resource availability constraining the supply of innovation. To this we add considerations of the pollution of that resource. 


\subsection{The empirical model}

Bretschger and Smulders (2007) emphasized that the dynamics of the depletion of natural resources needs to be researched by natural economics. Our main interest is to explore the effect of water utilization and water quality on economic growth and GDP itself across countries. We analyse the role of the ratio of water utilization and water quality in endogenous economic growth. Water is expressed in the model as both the ratio of water utilization, which stands as a proxy for water scarcity, ${ }^{1}$ and as water quality, which stands as a proxy for the value of wastewater treatment. The ratio of water utilization is calculated as:

$$
\rho=\frac{\text { Water withdrawal per capita }}{\text { Renewable water resources per capita }}
$$

The concept of water utilization intensity is not new; it was introduced by the United Nations Food and Agriculture Organization to classify areas that may be subjected to water shortages in the future (FAO, 1996; Sullivan, 2002). The ratio of water utilization that stands for the scarcity of water is used by Barbier (2004) as an indicator of relative water demand, and as a conceptual indicator of the amount of water utilized with respect to the available water resources in the economy. In addition to water utilization, we want to explore the effect of water quality on growth and GDP per capita; to apply this exploration we add biological oxygen demand (BOD) to our model.

Water quality/pollution is conceptually represented by $\mathrm{BOD}^{2}$ in terms of kg per day. Both Crapanzano et al. (2005) and Barua and Hubacek (2008) use this as an indicator of water quality. Higher values indicate greater pollution. The reasons for using this indicator are many. An important one is the availability of credible data from the World Bank database. Another is, as already noted, the popularity of this indicator in much of the literature concerned with water pollution. Scientifically, BOD is used as an

${ }^{1}$ Water use is divided into two kinds by hydrologists (Gleick, 2002): one kind is the freshwater resource withdrawn for direct human activities, and the second kind is water consumption. The idea behind developing the water poverty index (Sullivan, 2002) is to create an assessment system in order to monitor the places that are in need of water and provide the required water for these places, so they can achieve the required development. Different ratios illustrate the degree of interaction between humans and the sustainability of the water resources plus the local water stress index (Vörösmarty et al., 2000). In general, hydrologists usually represent the water stress and scarcity as water availability per person (cubic metres per person per year) or as the relative water demand (the ratio of water withdrawals to total freshwater resources per year).

2 BOD, also known as biochemical oxygen demand, is the amount of dissolved oxygen needed by aerobic biological organisms in a body of water to break down organic material present in a water sample at a certain temperature over a specific time period. BOD is used as a gauge of the effectiveness of wastewater treatment plants. It is listed as a conventional pollutant in the US Clean Water Act (Sawyer et al., 2003). 
assessment of the damage caused by water pollution ${ }^{3}$; it reflects the quality of water. The costs of water treatment in general are shared among all of the economic sectors. However, BOD reflects only organic pollution and excludes the chemical and thermal causes of pollution (Crapanzano et al., 2005). Nonetheless, it still measures an important aspect of water quality. Moreover, Gürlük (2009) does find a nonlinear relationship with GDP per capita, but fails to test for nonlinearity. The biggest sector impact on BOD in most countries is food, followed by textiles, paper and pulp, and chemicals. Apart from chemicals, these are found in all types of countries and hence, on these grounds, there is no obvious reason to link BOD with the level of development of a country. Nonetheless, this relationship between pollution and GDP per capita is one that warrants further analysis.

Generally, water quality here stands as a proxy for the value of wastewater treatment, which Briscoe (1996: 185) suggests measures the value of environmental quality. The water pollution variable reflects the waste accumulation and the irreversibility of the damage taking place in the environment and the ecosystem (Smulders, 1999). Specifically we argue that pollution is bad for growth. Water is a factor of production, water pollution impacts adversely on the quality of this input and will, we argue, reduce both growth and GDP itself. Much of the previous literature linking water and economic growth neglected pollution. Thus they also ignored the depletion of natural resources during the modelling of economic growth, which contributed to the failure of water development projects whose effect on growth is one of the main dimensions of the environmental Kuznets curve (EKC). However, in modelling long-run endogenous growth under optimal policy designs, Mohtadi (1996) used the environment as a factor of production in both the utility and the production functions. In doing so, he established that the optimal growth of any country is directly affected by environmental policies and regulations.

To set up the model, following the literature, the ratio of water utilization $\rho$ (Barbier, 2004) and BOD as an indicator of water quality (Barua and Hubacek, 2008), are used. Both are included in a quadratic form. The inclusion of $\rho$ as a quadratic follows the approach of Barbier (2004). It allows for either a flattening (or less likely, an explosion) of the curve, or a turning

${ }^{3}$ BOD is used in water quality monitoring (European Environment Agency, EEA, http:/ / www.eea.europa.eu/data-and-maps/indicators/freshwater-quality).

What supports our choice for this indicator here is that it can give an empirical assessment for the wastewater treated; it was designed to assess the impact of point-source organic effluents on source waters and is not generally suitable for environmental monitoring (Source: http://www.un.org/esa/sustdev/natlinfo /indicators/methodology_sheets/freshwater/biochemical_oxygen_demand.pdf). According to the UN, the indicator for water treatment is the proportion of wastewater that is treated before being discharged into the environment. Again, according to the UN, the limitations for this indicator stem from the fact that "This indicator provides information about wastewater volumes generated by point sources but not about wastewater volumes generated and discharged by diffuse sources" (Source: http:/ /www.un.org/esa/sustdev/natlinfo/ indicators/methodology_sheets/freshwater/waste_water_treatment.pdf). 
point. This can be regarded as incorporating both the direct and indirect effects of these variables on growth. The indirect effects come via their influences on other variables that consequently impact growth. It is to these that we now turn.

The analysis of growth encompasses a wide literature that analysed growth for different purposes. The additional explanatory variables here are chosen to increase the robustness of the analysis. Several elements of the literature (for example, Levine and Renelt, 1992; Sala-I-Martin, 1999) explored the variables that are important determinants of growth. As we are examining growth, the explanatory variables widely used in the previous literature as affecting growth should also be included in our considerations. We chose these variables based on the availability of credible data that covers a sufficiently long period of time (1960-2009), and a substantial pool of countries that represent different continents and income per capita. These variables are included in a matrix $\mathbf{X}$ in the following equation:

$$
\text { Growth }_{i t}=\beta_{0}+\beta_{1} \rho_{i t}+\beta_{2} \rho_{i t}^{2}+\beta_{3} \mathrm{BOD}_{i t}+\beta_{4} \mathrm{BOD}_{i t}^{2}+\beta_{5} \mathrm{X}_{i t}+\varepsilon_{i t}
$$

where $i$ denotes the country and $t$ time, and $\varepsilon$ is a white noise error term of the regression. $X_{i t}$ includes GDP per capita, scholar primary enrolment, and scholar secondary enrolment. The first and second school enrolment rates variables are used as proxies for human capital; these variables have been used based on the original year to represent the initial stock of capital (Barro, 1991; Sala-I-Martin, 1999; Temple, 1999; Barbier, 2004). School enrolments are used here as conceptual indicators to proxy the impact of human capital on growth.

We also include the impact of governance factors, including the political situation in individual countries. As for political and civil liberties, the higher the degree of democracy in the society, the greater the influence of the interest groups that focus on environmental protection and sustainability (Shafik and Bandyopadhyay, 1992). Democracy and good governance may, for example, act as a stimulus to innovation and investment, thus stimulating growth. The indicators that reflect political influence are an index of political rights that measures the rights to free elections, and the rights to the existence of different political parties, as well as the decentralization of the official power. Hence, we choose the variables corruption and political rights index. Corruption is used as an assessment of corruption within the political system.

In exploring the link between economic policy and environmental quality across countries, Shafik and Bandyopadhyay (1992) argue that an open economy in higher income countries focuses on capital intensive, and consequently, more pollution-intensive activities, whereas an open economy in low income countries is more concentrated on labour intensive, and consequently, less polluting activities. At the same time, openness and competition tend to increase the investment in innovation and technology and thus stimulate growth and GDP. In our analysis we use trade as a percentage of GDP to indicate openness, and as a proxy for the rate of investments. 
The explanatory variables include those which may impact growth, and those which moderate the impact of water shortage and quality of water on growth. The latter impact is our main focus and hence dictates this approach. Human capital does the latter; human capital is knowledge and the ability that humans have, which facilitates the efficient use of water. Humans negatively impact water quality with some of their actions, but that is different, although of course the primary impact of a human capital variable will be via its traditional impact on growth. This dual impact may also be true of other variables. We add the Gini index to the model to represent the effect of inequality on the allocation of natural resources and its effect on growth. The interaction between humans and the environment is a crucial part of sustainability theory (WCED, 1987). The inequalities in income increase the divisions in society that have an important impact on the nature of this interaction. Gylfason and Zoega (2002) demonstrated that the distribution of natural resources proved to be linked to inequality in the distribution of wealth, i.e., inequality in the distribution of income, education or land is connected to the contribution and share of natural resources in the national income. In other words, inequality in income reflects an inequality in the distribution of natural resources. Morevover, various parts of the literature shed light on the relationship between environmental quality and inequality. Boyce et al. (1999) recorded the effects of power inequalities between winners and losers with respect to the pollution level. In our case, we are concerned that resource inequality limits the impact of aggregate resources, specifically with respect to water and water quality on growth, but we also wish to capture the other potential impacts of inequality on growth.

Inflation is added to the model because most of the literature links inflation negatively to growth. Here too inflation, particularly in developing countries, is linked to food prices and food prices to water availability. Food and water are of central importance in every society and are directly related to the availability of water resources, whether in irrigation, canning, manufacturing or transporting. Of course, there are potential endogeneity problems with including inflation, particularly with respect to growth as the left hand side variable. However, as long as we are modelling growth we cannot disregard the potential impact of inflation.

Population growth adds to the demand for water resources, hence, may again limit the impact of available water on economic growth, and is included in the analysis. The modelling of the effect of water utilization on growth deals with water as an economic input and as a public good. The more open, democratic and developed the society, the more efficient policies and institutions may be in managing the natural resource, and in facilitating growth per se.

\subsection{Data, data sources and descriptive statistics}

The water data are from the AQUASTAT (FAO, 2010) update of the renewable water resources and the total water withdrawal per capita. Previous studies such as Barbier (2004) used the Gleick databases 1998 and 2006. The constraint in using just the Gleick database is due to the availability of only one year of data, not a series of years or time series data. We 
use the data from the AQUASTAT database supported by Gleick's water databases (Gleick, 1998, 2000; Gleick and Cooley, 2006). ${ }^{4}$ This allows us to substantially expand the data set. ${ }^{5}$

The analysis is based on monitoring the effect of water utilization per capita and BOD on economic growth - as well as the level of GDP - across countries, using a panel analysis of 177 countries. The countries are listed in table A1, appendix A. The calculations of the ratio of water utilization are obtained by applying the definition given in equation (5) that is used by Barbier. This is derived by dividing the annual water withdrawal per capita for the individual country by the annual renewable water resources per capita for that country.

We based inflation on the GDP deflator due to the availability of accredited data in the World Bank Development Indicators database. The remaining variables are GDP per capita (in constant 2000 US\$) and population growth (annual per cent), and are also obtained from the World Bank Development Indicators database.

We summarize all of the data definitions and sources in table 2. Table 3 contains the descriptive statistics of the explanatory variables. Missing observations are interpolated using STATA. ${ }^{6}$ The variables we are interpolating are ones which change steadily over time rather than ones which are dominated by stochastic shocks, and hence the interpolations are likely to be reasonably accurate.

\subsection{Estimation framework}

The analysis is done on two different dependent variables, so that each group embodied two different sets of panels:

- Panels for the effect of water utilization and BOD on per capita GDP at year $t$. GDP per capita is, of course, not growth, but represents the prosperity of a country. So equation (6) is used for two dependent variables:

$$
Y_{i t}=\beta_{0}+\beta_{1} \rho_{i t}+\beta_{2} \rho_{i t}^{2}+\beta_{3} \mathrm{BOD}_{i t}+\beta_{4} \mathrm{BOD}_{i t}^{2}+\beta_{5} \mathrm{X}_{i t}+\varepsilon_{i t}
$$

where $Y_{i t}=$ GDP per capita in the first regression, and $Y_{i t}=$ Growth in the second regression. It is possible that the impact of variables such as water and pollution on GDP per capita may be different from growth. GDP per capita depends on the available resources and how efficiently they are used. Growth reflects any increases and/or decreases in resources, and may reflect increases in their efficiency of use and any growth of knowledge.

${ }^{4}$ Gleick, in his database, used the AQUASTAT database as a source for some data. Moreover, the units of evaluation of water resources and withdrawal are the same.

${ }^{5}$ Some of the missing water withdrawal per capita data are calculated based on the AQUASTAT database. The calculations are done by dividing the total water withdrawal by the total population. The annual freshwater withdrawal obtained from AQUASTAT is in units of $10^{9}$ cubic meter/year per capita.

${ }^{6}$ We interpolated water data using STATA. The interpolation program is available on request. 
Table 2. Variables definitions

\begin{tabular}{|c|c|c|}
\hline Variable & Definition & Source \\
\hline $\mathrm{BOD}^{*}$ & $\begin{array}{l}\text { Biological Oxygen Demand (BOD) } \\
\text { in kg per day }\end{array}$ & World Bank Database \\
\hline Water utilization & $\begin{array}{l}\text { Annual water withdrawal per } \\
\text { capita/ Annual renewable } \\
\text { water resources per capita }\end{array}$ & $\begin{array}{l}\text { AQUASTAT } \\
\text { (FAO, 2010) }\end{array}$ \\
\hline GDP per capita* & $\begin{array}{l}\text { GDP per capita (constant } 2000 \\
\text { US\$) }\end{array}$ & World Bank Database \\
\hline Gini index* & $\begin{array}{l}\text { Measures the extent to which } \\
\text { the distribution of income } \\
\text { among individuals or house- } \\
\text { holds within an economy } \\
\text { deviates from a perfectly equal } \\
\text { distribution }\end{array}$ & World Bank Database \\
\hline Inflation* & Based on the GDP deflator & World Bank Database \\
\hline $\begin{array}{l}\text { Population } \\
\text { growth* }\end{array}$ & Annual \% & World Bank Database \\
\hline $\begin{array}{l}\text { Scholar primary } \\
\text { enrolment* }\end{array}$ & $\begin{array}{l}\text { Net enrollment rate is the ratio of } \\
\text { children of official school age } \\
\text { who are enrolled in school to the } \\
\text { population of the corresponding } \\
\text { official school age }\end{array}$ & World Bank Database \\
\hline $\begin{array}{l}\text { Scholar sec- } \\
\text { ondary } \\
\text { enrolment* }\end{array}$ & $\begin{array}{l}\% \text { net, the ratio of children } \\
\text { of official school age who } \\
\text { are enrolled in school to the } \\
\text { population of the corresponding } \\
\text { official school age. }\end{array}$ & World Bank Database \\
\hline $\begin{array}{l}\text { Political rights } \\
\text { index (1972- } \\
\text { 2008) }\end{array}$ & $\begin{array}{l}\text { The political rights index measures } \\
\text { the degree of freedom in the } \\
\text { electoral process, political } \\
\text { pluralism and participation and } \\
\text { the functioning of government. } \\
\text { Numerically, Freedom House } \\
\text { rates political rights on a scale } \\
\text { of } 1 \text { to } 7\end{array}$ & $\begin{array}{l}\text { Freedom House } \\
\text { database last } \\
\text { updated } 2008\end{array}$ \\
\hline $\begin{array}{l}\text { Corruption } \\
\quad(1984-2009)\end{array}$ & $\begin{array}{l}\text { This is an assessment of corruption } \\
\text { within the political system } \\
\text { (Howell, 2011). }\end{array}$ & $\begin{array}{l}\text { International Country } \\
\text { Risk Guide } \\
\text { Methodology }\end{array}$ \\
\hline $\begin{array}{l}\text { Trade as a } \\
\text { percentage of } \\
\mathrm{GDP}^{*}\end{array}$ & $\begin{array}{l}\text { Trade is the sum of exports and } \\
\text { imports of goods and services } \\
\text { as \% of GDP }\end{array}$ & World Bank Database \\
\hline
\end{tabular}

*Definition given by the World Bank

- To see the effect on economic growth of $\rho$ and BOD over a longer period, we build on Barbier's model (2004) which used a range of five-year growth. In taking the rate of five-year growth, calculations are done by taking the percentage of growth from year $t$ until year $(t+5)$ and regressed on $\rho$ and BOD at year $t$. In the context of 
Table 3. Descriptive statistics

\begin{tabular}{|c|c|c|c|c|c|}
\hline Variable & Observations & Mean & $\begin{array}{l}\text { Standard } \\
\text { deviation }\end{array}$ & Min & $\operatorname{Max}$ \\
\hline Year & 8850 & 1984.5 & 14.43169 & 1960 & 2009 \\
\hline $\begin{array}{l}\text { Annual water } \\
\text { resources per capita }\end{array}$ & 8400 & 40662.82 & 103864.7 & 0 & 934184.6 \\
\hline BOD & 4950 & 0.2258 & 0.7168 & 0.000109 & 7.1648 \\
\hline Corruption & 3306 & 3.024816 & 1.369 & 0 & 6.166 \\
\hline GDP per capita & 6822 & 5254.212 & 8042.217 & 0.0213 & 59182.83 \\
\hline Gini index & 7450 & 40.94216 & 13.6219 & 18.0016 & 79.5176 \\
\hline Inflation & 6795 & 42.3905 & 492.5917 & -33.532 & 26762.02 \\
\hline Political rights index & 5711 & 3.972334 & 2.238 & 1 & 7 \\
\hline Population growth & 8760 & 1.8828 & 1.5421 & -8.505 & 17.74 \\
\hline $\begin{array}{l}\text { Ratio of water } \\
\text { utilization }(\rho)\end{array}$ & 8350 & 0.4226 & 2.017465 & 2.44E-05 & 19.819 \\
\hline $\begin{array}{l}\text { Scholar primary } \\
\text { enrolment }\end{array}$ & 8550 & 97.4400 & 6.7882 & 24.533 & 100.008 \\
\hline $\begin{array}{l}\text { Scholar secondary } \\
\text { enrolment }\end{array}$ & 7750 & 98.4772 & 2.4578 & 74.577 & 99.4303 \\
\hline Trade as $\%$ of GDP & 6731 & 73.4019 & 43.656 & 0.3088 & 438.09 \\
\hline $\begin{array}{l}\text { Withdrawal water } \\
\text { per capita }\end{array}$ & 8850 & 533.3876 & 699.896 & 11.9159 & 6424.366 \\
\hline
\end{tabular}

equation (7) we used the five-year growth as the basis for the analysis for three reasons. First, to see the effect over a longer period of time, over which the impact of an increase in an independent variable can be expected to have had a substantial impact. Five years tends to represent a single business cycle for many countries. Ten years would represent two business cycles. The second reason is to compare our analysis with the previous literature (e.g., Barbier, 2004). Thirdly, there is the argument that a five-year horizon reduces the fluctuations in the business cycle and allows a concentration on the fundamentals. Others have also tended to use a five-year average to present data (e.g., Barro and Lee, 1993).

We used an unbalanced panel for 177 countries covering the period from 1960 until 2009. The equation for the fixed effects model becomes:

$$
\text { Growth }_{i t}=\beta_{0}+\beta_{1} \rho_{i t}+\beta_{2} \rho_{i t}^{2}+\beta_{3} \mathrm{BOD}_{i t}+\beta_{4} \mathrm{BOD}_{i t}^{2}+\beta_{5} \mathrm{X}_{i t}+\alpha_{i}+\varepsilon_{i t}
$$

where $\alpha_{i}(i=1 \ldots n)$ is the unknown intercept for each entity with $n$ entityspecific intercepts. The attractiveness of the panel data analysis is found in the high number of observations and greater degrees of freedom due to more observations. This approach also allows a solution to the problem of omitted variables heterogeneity. Specifically, it can control for individual, specific, time-invariant characteristics and their unobserved heterogeneity, whose presence may lead to biased estimators in the standard ordinary 
least squares (OLS) estimator. We thus used fixed effects to study the impact of variables that vary over time. As such, we explore the relationship between the dependent and the explanatory variables, and omit the effects of time-invariant characteristics from the explanatory variables (Hausman and Taylor, 1981). Moreover, the fixed effects picks up any significant difference between countries: 'the crucial distinction between fixed and random effects is whether the unobserved individual effect embodies elements that are correlated with the regressors in the model, not whether these effects are stochastic or not' (Greene, 2008: 183). We also cannot ignore the influence of the geography and the region that is systematically affected by climatic influences and, for this as well as other reasons, may impact growth. The fixed effects model captures these individual countries' effects, which can affect the regression results within the context of different models.

We estimate our models using a robust estimate for the standard errors to control for heteroskedasticity. The correlation coefficient test indicates the presence of a correlation between the $x$ and the $x^{2}$ (i.e., the two quadratic form variables) in the model, but the mean variance inflation factor gives an accepted value, as $x^{2}$ is an interaction term of itself; $x$ and $x^{2}$ will obviously be reasonably collinear.

For this reason we just report the results with fixed effects. In our analysis, we are exploring the effect of water quality that is expressed by BOD as an exogenous variable in the endogenous growth model. There is potentially a causal effect between growth and BOD. It is almost a stylized fact that growth causes pollution; this can impact the regression results and may result in a biased estimator. That is why some of the regressors are correlated with the error term $\operatorname{cov}\left(x_{i k}, u_{i}\right) \neq 0$. In this case, the regression analysis needs further treatment to deal with the causality effect of the regressors on the dependent variable. To deal with the potential problems, we use the instrumental variable technique in the fixed effects model. ${ }^{7}$

An important issue in our regression that we need to take into consideration is that we are using environmental variables and socio-economic variables. Thus, finding external instrumental variables is often a challenging task. ${ }^{8}$ The variables that we have chosen affect the quality of the environment through the effect on greenhouse gases (GHGs). For this task, we have to identify the aspects, ${ }^{9}$ in addition to their environmental impacts, that cause harm to the quality of the environment - whether

7 This instrumented variable is an exogenous variable that is correlated with the endogenous variable but not with the error terms $\operatorname{cov}\left(I V_{i t}, u_{i}\right)=0$.

8 The variables used for instrumentation are methane emissions in the energy sector (thousand metric tons of $\mathrm{CO}_{2}$ equivalent), and $\mathrm{SF}_{6}$ (sulfur hexafluoride) gas emissions (thousand metric tons of $\mathrm{CO}_{2}$ equivalent). They are chosen for their substantial effects on the water quality and due to the credibility of the data (Source: World Bank Development report). See the regression results in table B1 in appendix B.

9 Aspects are substances and materials produced by businesses' activities, or products or services that can interact with the environment, and their environmental impacts, which are defined by the ISO (ISO 14001:2004) for environmental 
directly or indirectly. In the case of water quality, these aspects could be the discharge of wastes in water, and the impact is the damage to the aquatic system.

We rerun the regression with the instrumental variables and use the Davidson-MacKinnon test to test for exogeneity after the fixed effects instrumental variable model. The acceptance of the null $(p>0.05)$ indicates that the model with the instrumental variables is not significant; in other words, the endogenous regressors do not affect the regression results in the fixed effects model, instrumenting BOD is not required ${ }^{10}$ and the ordinary fixed-effects estimations in column 2 of the regression tables are consistent. The results of the tests are reported in tables 4 and 5 .

For better illustration of the model we use two specifications. The first specification introduces the model with the ratio of water utilization ( $\rho$ and $\rho^{2}$ ) that is present in column 1 in tables 4 and 5 . We use this specification to compare our results with Barbier's (2004). The second specification includes both $\left(\rho+\rho^{2}\right)$ and water quality (BOD and BOD $\left.{ }^{2}\right)$ to see the effect of different specifications within the model context (column 2 in tables 4 and 5). We calculated the turning points ${ }^{11}$ of $\rho$ and BOD using the models in column 2 (tables 4 and 5), where it represents the peak impacts of $\rho$ and BOD in the same fixed effects model.

To test the robustness of our model, we rerun the regression excluding the countries that are excluded by Mankiw et al. (1992), these being the oil producing countries. ${ }^{12}$ We get similar results with a negligible change in the coefficients of the variables. We also exclude inflation from our model due to potential endogeneity between growth and inflation; we again get similar results. Our main focus is on the impact of the environmental variables; nonetheless, we further replaced the inflation with a proxy variable, the international rate of inflation, and again got similar results.

\section{Results}

The goodness of fit values (based on the F statistics) suggest the rejection of the null hypothesis that all coefficients are zero. It is also clear that there is a significant effect of the ratio of water withdrawal on GDP per capita, and on the rate of five-year growth (column 1 in tables 4 and 5). That expands on the results given by Barbier (2004), who mentioned that the database he

management systems as 'any change in the environment whether adverse or beneficial, wholly or partially resulting from an organization's activities, products, or services.'

10 According to Baum and Stillman (1999) a rejection indicates that the instrumental variables fixed effects estimator should be employed. See Davidson and MacKinnon (1993: 237-240) and Wooldridge (2000: 483-484).

${ }^{11}$ We calculated the turning pints by equating the first-order derivative of $\beta_{1} \rho+$ $\beta_{2} \rho^{2}$ to zero and solving similarly for $\beta_{3} B O D+\beta_{4} B O D^{2}$.

12 Countries are Bahrain, Gabon, Iran, Iraq, Kuwait, Lesotho, Oman, Saudi Arabia and the United Arab Emirates. 
Table 4. Regression analysis of water utilization and BOD with Log GDP per capita as a dependent variable

\begin{tabular}{|c|c|c|}
\hline & $F E$ & $F E$ \\
\hline & Column 1 & Column 2 \\
\hline Constant & $\begin{array}{l}-15.02^{* * *} \\
\quad(5.05)\end{array}$ & $\begin{array}{l}-43.77^{* * *} \\
(15.01)\end{array}$ \\
\hline$\rho$ & $\begin{array}{l}0.189^{*} \\
(2.49)\end{array}$ & $\begin{array}{l}0.220^{\text {*** }} \\
(3.97)\end{array}$ \\
\hline$\rho^{2}$ & $\begin{array}{c}-0.419^{*} \\
(2.16)\end{array}$ & $\begin{array}{l}-0.548^{* * *} \\
(3.86)\end{array}$ \\
\hline BOD & & $\begin{array}{l}0.472^{* * *} \\
(5.28)\end{array}$ \\
\hline $\mathrm{BOD}^{2}$ & & $\begin{array}{c}-0.958^{* * *} \\
(4.45)\end{array}$ \\
\hline Gini index & $\begin{array}{l}0.705^{* * *} \\
(22.34)\end{array}$ & $\begin{array}{l}1.039^{* * *} \\
(29.58)\end{array}$ \\
\hline Inflation & $\begin{array}{c}-0.0003 \\
(0.60)\end{array}$ & $\begin{array}{c}-0.0001 \\
(0.08)\end{array}$ \\
\hline Population growth & $\begin{array}{l}0.026^{* * *} \\
(5.01)\end{array}$ & $\begin{array}{l}0.037^{* * *} \\
(7.83)\end{array}$ \\
\hline Political rights index & $\begin{array}{r}0.02^{*} \\
(2.21)\end{array}$ & $\begin{array}{l}0.02^{* * *} \\
(5.64)\end{array}$ \\
\hline Corruption & $\begin{array}{c}-0.03^{* * *} \\
(6.33)\end{array}$ & $\begin{array}{c}-0.013^{* *} \\
(3.10)\end{array}$ \\
\hline Scholar primary enrolment & $\begin{array}{l}0.003^{*} \\
(2.29)\end{array}$ & $\begin{array}{l}0.005^{* * *} \\
(4.49)\end{array}$ \\
\hline $\begin{array}{l}\text { Scholar secondary } \\
\text { enrolment }\end{array}$ & $\begin{array}{c}-0.00471^{*} \\
(2.37)\end{array}$ & $\begin{array}{l}0.001 \\
(0.49)\end{array}$ \\
\hline Trade as $\%$ of GDP & $\begin{array}{l}0.00131^{* * * *} \\
(6.2)\end{array}$ & $\begin{array}{l}0.001^{* * *} \\
(5.22)\end{array}$ \\
\hline Observations & 2459 & 1590 \\
\hline$R^{2}$ & $0.407^{* * *}$ & $0.687^{* * *}$ \\
\hline Adjusted $R^{2}$ & 0.376 & 0.67 \\
\hline RMSE & 0.142 & 0.103 \\
\hline Hausman test & $146.90^{* * *}$ & $293.91^{* * *}$ \\
\hline
\end{tabular}

Notes: $t$ statistics are in parentheses; ${ }^{* * *}$ significant at 1 per cent level, ** significant at 5 per cent level, * significant at 10 per cent level.

Modified Wald test for groupwise heteroskedasticity in fixed effect regression model $\left(H_{0}: \sigma(i)^{2}=\sigma^{2}\right.$ for all $\left.i\right)$ is $65937.73^{* * *}$, indicating a heteroskedasticity which is alleviated by using the heteroskedasticity-robust standard errors. The mean value of the variance inflation factors of the overall variables in the models is 9.86

The significance of $R^{2}$ is based on F statistics.

Davidson-MacKinnon test of exogeneity: $0.0431282 \mathrm{~F}(1,1506)$

$P$-value $=0.8355$

In column 2: Turning point $\rho$ : 0.20, turning point BOD: 0.25 .

RMSE: root mean squared error 
Table 5. Regression analysis of water utilization and BOD with the rate of five-year growth as a dependent variable

\begin{tabular}{|c|c|c|}
\hline & $F E$ & $F E$ \\
\hline Variable & Column(1) & Column(2) \\
\hline Constant & $\begin{array}{r}-1095.0^{* * *} \\
(4.64)\end{array}$ & $\begin{array}{r}-233.5 \\
(0.77)\end{array}$ \\
\hline Log GDP per capita & $\begin{array}{l}26.92^{* * *} \\
(14.26)\end{array}$ & $\begin{array}{l}31.16^{* * *} \\
(14.19)\end{array}$ \\
\hline$\rho$ & $\begin{array}{l}4.188^{* * *} \\
(3.68)\end{array}$ & $\begin{array}{c}4.72 \\
(0.43)\end{array}$ \\
\hline$\rho^{2}$ & $\begin{array}{l}-1.024^{* * *} \\
(3.43)\end{array}$ & $\begin{array}{c}-9.813 \\
(0.35)\end{array}$ \\
\hline BOD & & $\begin{array}{l}-7.496^{* * *} \\
(9.94)\end{array}$ \\
\hline $\mathrm{BOD}^{2}$ & & $\begin{array}{l}1.426^{* * *} \\
(7.64)\end{array}$ \\
\hline Gini index & $\begin{array}{l}-0.330^{* * *} \\
(3.44)\end{array}$ & $\begin{array}{l}-0.439^{* * *} \\
(4.08)\end{array}$ \\
\hline Inflation & $\begin{array}{l}-0.0014^{* * *} \\
(3.78)\end{array}$ & $\begin{array}{c}-0.069^{* * *} \\
(5.58)\end{array}$ \\
\hline Population growth & $\begin{array}{l}-4.595^{* * *} \\
(7.81)\end{array}$ & $\begin{array}{l}-5.988^{* * *} \\
(8.32)\end{array}$ \\
\hline Political rights index & $\begin{array}{c}0.122 \\
(0.38)\end{array}$ & $\begin{array}{r}0.255 \\
(0.71)\end{array}$ \\
\hline Corruption & $\begin{array}{c}0.432 \\
(1.16)\end{array}$ & $\begin{array}{c}0.19 \\
(0.46)\end{array}$ \\
\hline Scholar primary enrolment & $\begin{array}{l}0.103^{* *} \\
(2.61)\end{array}$ & $\begin{array}{l}0.0375 \\
(0.81)\end{array}$ \\
\hline Scholar secondary enrolment & $\begin{array}{l}0.426^{* *} \\
(2.97)\end{array}$ & $\begin{array}{r}0.264 \\
(1.84)\end{array}$ \\
\hline Trade as $\%$ of GDP & $\begin{array}{l}0.068^{* *} \\
(3.3)\end{array}$ & $\begin{array}{l}0.086^{* * *} \\
(3.91)\end{array}$ \\
\hline Observations & 1418 & 1005 \\
\hline$R^{2}$ & $0.291^{* * *}$ & $0.360^{* * *}$ \\
\hline Adjusted $R^{2}$ & 0.232 & 0.306 \\
\hline RMSE & 8.411 & 7.571 \\
\hline Hausman test & $37.33^{* * *}$ & $220.51^{* * *}$ \\
\hline
\end{tabular}

Notes: $t$ statistics are in parentheses; ${ }^{* * *}$ significant at $1 \%$ level, ${ }^{* *}$ significant at $5 \%$ level, *significant at $10 \%$ level.

Modified Wald test for groupwise heteroskedasticity in fixed effect regression model $\left(H_{0}: \sigma(i)^{2}=\sigma^{2}\right.$ for all $\left.i\right)$ is $89498.23^{* * *}$, indicating a heteroskedasticity which is alleviated by using the heteroskedasticity-robust standard errors. The mean value of the variance inflation factors of the overall variables in the models is 8.73.

The significance of $R^{2}$ is based on $\mathrm{F}$ statistics.

Davidson-MacKinnon test of exogeneity: $0.4395 \mathrm{~F}(1,925) P$-value $=0.5075$

In column 2: Turning point $\rho: 0.24$, turning point BOD: 2.677.

RMSE: root mean squared error 
used limited his work from using the cross-section time series analysis for the relationship between $\rho$ and growth. He then pointed out that, 'Thus, the following empirical analysis must be considered only a preliminary test of the theoretical model, as the results obtained may arise from the use of our limited cross-country data set. A more robust test of the theory must wait until a better (i.e., pooled cross-sectional and time series) data set becomes available' (Barbier, 2004: 8).

Considering the socio-economic variables, the Gini index is significant and negative in the five-year growth model (table 5), which is as expected. Inflation affects the rate of five-year growth at the 1 per cent significance level. An increase in inflation by 1 per cent reduces five-year growth by 0.07 per cent.

The significant effect of the ratio of water utilization is apparent and consistent between the different models for the log of GDP per capita, where the effect shows an inverted U-shaped impact on the GDP per capita. BOD is also significant at the 1 per cent level on GDP per capita in both terms of the quadratic form (column 2, table 4). It appears to have an increasing effect on GDP per capita, and then turns at the critical point (turning point 0.2 ) where the operation costs exceed the benefits and then starts to decrease. This could be due to the effect of an increase on the input in part because the operational costs for the economy of dealing with pollution outweigh any further benefits. This is consistent with there being a finite capacity of an economy to absorb an accumulation of pollutants (López, 1994).

In table 5 there is clear evidence for the presence of an inverted U-shaped relationship of the effect of water utilization on growth. The regression results show an interaction between water quality and ratio of utilization in their effect on growth in the medium term. Specifically, the results show a significant impact of $\rho$ alone at a 1 per cent significance level on the rate of five-year growth (column 1, table 5). This significance disappears when we add BOD to the model; BOD is significant at the 1 per cent level for GDP per capita (column 2, table 4) and five-year growth (column 2, table 5). This indicates that the quality of water affects growth more than the quantity in the longer term. It also indicates the presence of a U-shaped curve in the effect of water quality on long-run growth. Moreover, the turning point is at the upper end of values we observe in practice, and in this case the turning point may simply be a function of using a quadratic form. In reality, it may be that the curve flattens out at higher levels of pollution rather than turns up.

Political rights, corruption and scholar enrolment were not significant in the growth equation. Taken together, this could suggest that these variables impact GDP per capita, but not its rate of growth. But care needs to be exercised; we are using fixed effects, which often absorb significance from slowly changing variables, and the sample size, although reasonably large, is also a constraining factor on the estimation. Finally, we tested for an interaction term between BOD and $\rho$. Thus for example, in the GDP per capita regression this was positively significant at the 5 per cent level. The significance of the other variables remained unchanged. This can be interpreted in a number of ways, for example, the initial positive impact of BOD 
on GDP is increased as $\rho$ increases. This is one of the issues that warrants further research.

Finally, in the regression related to GDP per capita we included an interactive term between BOD and $\rho$. This was significant at the 10 per cent level with a positive coefficient of 1.087 (see table C1 in appendix C). One interpretation of this is that the eventual negative impact of pollution on GDP is mitigated by higher levels of water utilization. So the effect of water utilization on GDP per capita is also influenced by the effect of water quality, and there is evidence of their interaction. This again is something that warrants further analysis.

\section{Conclusions}

The purpose of our study was to examine the effect of the ratio of water utilization together with the effect of water quality on endogenous economic growth across countries. We used panels of 177 countries based on the methodology of Barbier (2004) involving the ratio of water utilization. To this we added BOD as a measure of water quality and water pollution. In modelling endogenous growth, we added water quality to the growth model to correct for a weakness in previous growth models that led to their inefficiencies in testing the impact of water, in particular on short-run and long-run economic growth. Water pollution reflects the accumulation of waste and the irreversibility of the damage taking place in the environment and the ecosystem. The previous literature that modelled economic growth and the environment neglected this fact. Our analysis was concerned with whether these variables impact growth. Do water utilization and water pollution have impacts on economic growth? Or, for the latter, does economic growth have a capacity to absorb the accumulation of pollutants (López, 1994)?

Our empirical analysis strongly supports the presence of an inverted $U$ relationship in the effect of water scarcity on the economy in the short and the longer run. There is also evidence that the effect of water quality exceeds the effect of water quantity on growth. We have seen the impact of BOD on growth, which suggests that as long as water quality improves, growth increases. We have provided support for the hypothesis that water quality and quantity affect the macroeconomy. The growth model should not be restricted to socio-economic variables anymore because growth is affected by environmental variables as well. This emphasizes the interaction between the economy and environmental quality; our model substantiates the hypothesis that economic growth can be restricted by environmental quality. The fact that BOD has a positive impact (up to a certain point) on log GDP per capita, but has a statistically significant negative impact on the rate of five-year growth, suggests that, as indicated before, BOD is not without positive impacts on the economy in allowing some pollution-generating activities, but that there is a limit to this. The growth results suggest that most countries have already hit this limit and thus further growth is constrained by BOD.

The results show that as water utilization increases, so does growth, until a maximum point where a scarcity factor becomes relevant and the 
amount of water resources restricts growth; beyond this point growth starts to decrease (due to exploitation of the renewable water sources). There is evidence that both water utilization and BOD constrain growth. Water utilization may be managed as an economic resource, but even with increased efficiency it is difficult to reduce water utilization with the increase of population and industrialization that characterize the world today. However, water pollution can be mitigated and decreased in the short run, and even more so in the long run. This requires a willingness to change behaviour, and environmental policies are not strict in all regions of the world. Thus, water pollution may remain a persistent issue accompanying human activity. Nevertheless, improving water quality provides a new instrument to those seeking to maximize endogenous growth, and importantly, one which also supports rather than conflicts with other environmental aims.

We believe that the model with only the effect of the water utilization also reflects the impact of water quantity on the economy, whereas the model with the BOD together with the water utilization also describes how the quality of water affects the economy, and how pollution affects the deterioration of the natural resource. Water pollution adds a burden to the quality of the withdrawn water and adds more to the cost of production, which has an adverse impact on the growth of the economy. Arguably, our results show that quality is more important than quantity of water, as water quality is significant with respect to the regressions for both dependent variables while the quantity is significant in just one model.

We cannot decidedly claim that some countries can overcome limited water in using that water more efficiently. Some of the countries in the dataset are well endowed with water while lacking efficient water withdrawal and usage, and policies are definitely needed to improve water efficiency even when water quality is not a main issue, e.g. in the Po Basin in Northern Italy and several areas of Switzerland (see Bozzola and Swanson, 2014). Nonetheless, there are limits to which countries can overcome limited water supplies by using that water more efficiently. But BOD is different and offers the hope that by focusing on pollution, we can loosen some of the constraints of water on growth. Results are consistent with our expectations that as long as BOD decreases, growth increases in the long run.

\section{References}

Barbier, E.B. (1999), 'Endogenous growth and natural scarcity', Environmental and Resource Economics 14(1): 51-74.

Barbier, E.B. (2004), 'Water and economic growth', Economic Record 80(248): 1-16.

Barro, R.J. (1991), 'Economic growth in a cross section of countries', The Quarterly Journal of Economics 106(2): 407-443.

Barro, R.J. and J.W. Lee (1993), 'International comparisons of educational attainment', Journal of Monetary Economics 32(3): 363-394.

Barua, A. and K. Hubacek (2008), 'Water pollution and economic growth: an environmental Kuznets curve analysis at the watershed and state level', International Journal of Ecological Economics and Statistics 10: 63-78. 
Baum, C.F. and Stillman, S. (1999), 'DMEXOGXT: Stata module to test consistency of OLS vs XT-IV estimates', Statistical Software Components S401103, Boston College Department of Economics, revised 18 June.

Boyce, J., A. Klemer, P. Templet, and C. Wills (1999), 'Power distribution, the environment and public health: a state-level analysis', Ecological Economics 29(1): 127-140.

Bozzola, M. and T. Swanson (2014), 'Policy implications of climate variability on agriculture: water management in the Po river basin, Italy', Environmental Science E Policy 43: 26-38.

Bretschger, L. and J.A. Smulders (2007), 'Sustainable resource use and economic dynamics', Environmental and Resource Economics, 36(1): 1-13.

Briscoe, J. (1996), 'Water as an economic good: the idea and what it means in practice', Special Session R 11, International Commission on Irrigation and Drainage, World Congress, Cairo, Egypt, September.

Chambers, D. and J.T. Guo (2009), 'Natural resources and economic growth: some theory and evidence', Annals of Economics and Finance 10(2): 367-89.

Crapanzano, G., M. Pavan, and A. Hunt (2005), 'Valuation of water', in A. Markandya and M. Tamborra (eds), Green Accounting in Europe. Volume 2: A Comparative Study, Cheltenham: Elgar, pp. 363-380.

Davidson, R. and MacKinnon, J. (1993), Estimation and Inference in Econometrics, New York: Oxford University Press.

FAO (1996), 'Population Change-Natural Resources-Environment Linkages in the Arab States Region', Rome: FAO.

FAO (2010), 'AQUASTAT' [Available at] http:/ / www.fao.org/nr/water/aquastat/ data/query/index.html?lang=en

Fracasso, A. (2014), 'A gravity model of virtual water trade', Ecological Economics 108: $215-228$.

Freedom House (2008), Freedom in the World 2008: The Annual Survey of Political Rights and Civil Liberties, Washington DC: Freedom House.

Gleick, P.H. (1998), The World's Water 1998-99: The Biennial. Report on Fresh Water Resources, Washington DC: Island Press.

Gleick, P.H. (2000), The World's Water 2000-01: The Biennial Report on Fresh Water Resources, Washington DC: Island Press.

Gleick, P.H. (2002), The World's Water 2002-03: The Biennial Report on Freshwater Resources, Washington DC: Island Press.

Gleick, P.H. and H. Cooley (2006), The World's Water 2006-2007: The Biennial Report on Freshwater Resources, Washington D.C.: Island Press.

Greene, W.H. (2008), Econometric Analysis, 5th edn, Upper Saddle River, NJ: Prentice Hall

Gürlük, S. (2009), 'Economic growth, industrial pollution and human development in the Mediterranean region', Ecological Economics 68: 2327-2335.

Gylfason, T. and G. Zoega (2002), 'Inequality and economic growth: do natural resources matter?' CESifo (Center for Economic Studies and Ifo Institute) Working Paper Series No. 712. Munich, Germany.

Hausman, J.A. and W.E. Taylor (1981), 'Panel data and unobservable individual effects', Econometrica 49(5): 1377-1398.

Howell, L.D. (2011), International country risk guide methodology, East Syracuse, NY: The PRS Group.

Levine, R. and D. Renelt (1992), 'A sensitivity analysis of cross-country growth regressions', American Economic Review 82(4): 942-963.

López, R. (1994), 'The environment as a factor of production: the effects of economic growth and trade liberalization', Journal of Environmental Economics and Management 27(2): 163-184. 
Mankiw, N.G., D. Romer, and D. Weil. (1992), 'A contribution of the empirics of economic growth', Quarterly Journal of Economics 107(2):407-438.

Mohtadi, H. (1996), 'Environment, growth, and optimal policy design', Journal of Public Economics 63(1): 119-140.

Pacific Institute (2007), At the Crest of a Wave: A Proactive Approach to Corporate Water Strategy, Oakland, CA: Business for Social Responsibility and the Pacific Institute.

Sala-I-Martin, X. (1999), 'I just ran two million regressions', American Economic Review 87(2): 178-183.

Sawyer C.N., P.L. McCarty, and G.F. Parkin (2003), Chemistry for Environmental Engineering and Science, 5th edn, New York, NY: McGraw-Hill.

Shafik, N. and S. Bandyopadhyay (1992), Economic Growth and Environmental Quality: Time Series and Cross-Country Evidence, Washington DC: World Bank.

Smulders, S. (1999), 'Endogenous growth theory and the environment', in J.C.J.M. van den Bergh (ed.), Handbook of Environmental and Resource Economics, Cheltenham: Edward Elgar, pp. 610-621.

Sullivan, C. (2002), 'Calculating a water poverty index', World Development 30(7): 1195-1210.

Temple, J. (1999), 'The new growth evidence', Journal of Economic Literature 37(1): 112-156.

Vörösmarty, C.J., P. Green, J. Salisbury, and R.B. Lammers (2000), ‘Global water resources: vulnerability from climate change and population growth', Science 289(5477): 284-288.

WCED (1987), Our Common Future, Oxford: Oxford University Press.

WWAP (2009), 'Water in a Changing World: 3rd UN World Water Development Report', UNESCO, Paris.

Wooldridge, J. (2000), Introductory Econometrics: A Modern Approach, New York: South-Western College Publishing.

\section{Appendix A}

Table A1. List of 177 countries included in the study

\begin{tabular}{lll}
\hline Afghanistan & Central African R. & Georgia \\
Albania & Chad & Germany \\
Algeria & Chile & Ghana \\
Angola & China & Greece \\
Antigua and Barbuda & Colombia & Grenada \\
Argentina & Comoros & Guatemala \\
Armenia & Congo, D. R. & Guinea \\
Australia & Congo, Rep. & Guinea-Bissau \\
Austria & Costa Rica & Guyana \\
Azerbaijan & Cote d'Ivoire & Haiti \\
Bahrain & Croatia & Honduras \\
Bangladesh & Cuba & Hungary \\
Barbados & Cyprus & Iceland \\
Belarus & Czech Republic & India \\
Belgium & Denmark & Indonesia \\
\hline
\end{tabular}

(continued) 
Table A1. Continued

\begin{tabular}{|c|c|c|}
\hline Belize & Djibouti & Iran \\
\hline Benin & Dominica & Iraq \\
\hline Bhutan & Dominican R. & Ireland \\
\hline Bolivia & Ecuador & Israel \\
\hline Bosnia \& Herzegovina & Egypt & Italy \\
\hline Botswana & El Salvador & Jamaica \\
\hline Brazil & Equatorial Guinea & Japan \\
\hline Brunei D. & Eritrea & Jordan \\
\hline Bulgaria & Estonia & Kazakhstan \\
\hline Burkina Faso & Ethiopia & Kenya \\
\hline Burundi & Fiji & Korea, D.R. \\
\hline Cambodia & Finland & Korea, Rep. \\
\hline Cameroon & France & Kuwait \\
\hline Canada & Gabon & Kyrgyz Republic \\
\hline Cape Verde & Gambia & Lao PDR \\
\hline Latvia & Norway & St. Vincent and the Grenadines \\
\hline Lebanon & Oman & Sudan \\
\hline Lesotho & Pakistan & Suriname \\
\hline Liberia & Panama & Swaziland \\
\hline Libya & Papua New Guinea & Sweden \\
\hline Lithuania & Paraguay & Switzerland \\
\hline Luxembourg & Peru & Syria \\
\hline Macedonia, FYR & Philippines & Tajikistan \\
\hline Madagascar & Poland & Tanzania \\
\hline Malawi & Portugal & Thailand \\
\hline Malaysia & Puerto Rico & Timor-Leste \\
\hline Maldives & Qatar & Togo \\
\hline Mali & Romania & Trinidad and Tobago \\
\hline Malta & Russian Federation & Tunisia \\
\hline Mauritania & Rwanda & Turkey \\
\hline Mauritius & Sao Tome and Principe & Turkmenistan \\
\hline Mexico & Saudi Arabia & Uganda \\
\hline Moldova & Senegal & Ukraine \\
\hline Mongolia & Serbia & United Arab Emirates \\
\hline Morocco & Seychelles & United Kingdom \\
\hline Mozambique & Sierra Leone & United States \\
\hline Myanmar & Singapore & Uruguay \\
\hline Namibia & Slovak Republic & Uzbekistan \\
\hline Nepal & Slovenia & Venezuela \\
\hline Netherlands & Somalia & Vietnam \\
\hline New Zealand & South Africa & West Bank and Gaza \\
\hline Nicaragua & Spain & Yemen \\
\hline Niger & Sri Lanka & Zambia \\
\hline Nigeria & St. Lucia & Zimbabwe \\
\hline
\end{tabular}




\section{Appendix B}

Table B1. Regression results of the effect of methane emissions in energy sector and $\mathrm{SF}_{6}$ with $\mathrm{BOD}$ (for 2001-2009) as the dependent variable

\begin{tabular}{lc}
\hline Variable & OLS model \\
\hline Constant & $0.198^{* * * *}$ \\
Methane emissions in the energy sector & $(7.96)$ \\
& $0.406^{* * * *}$ \\
$\mathrm{SF}_{6}$ gas emissions & $(3.40)$ \\
& $0.375^{* *}$ \\
$N$ & $(2.71)$ \\
$R^{2}$ & 688 \\
Adjusted $R^{2}$ & 0.076 \\
F statistics & 0.073 \\
RMSE & $28.24^{* * *}$ \\
\end{tabular}

Notes: Prob > F - This is the p-value associated with the above F-statistic. It is used in testing the null hypothesis that all of the model coefficients are 0 .

\section{Appendix C}

Table C1. Regression results of water utilization and BOD with the interaction term on Log GDP per capita

\begin{tabular}{|c|c|}
\hline Dependent variable: $\log$ GDP per capita & OLS model \\
\hline Constant & $\begin{array}{c}7.465^{\text {**** }} \\
(211.91)\end{array}$ \\
\hline$\rho$ & $\begin{array}{l}0.247^{* *} \\
(2.88)\end{array}$ \\
\hline$\rho^{2}$ & $\begin{array}{c}-0.03^{* * *} \\
(5.53)\end{array}$ \\
\hline BOD & $\begin{array}{l}0.165^{* * *} \\
(13.3)\end{array}$ \\
\hline $\mathrm{BOD}^{2}$ & $\begin{array}{l}-0.303^{* * *} \\
(19.75)\end{array}$ \\
\hline$\rho \mathrm{BOD}$ (interaction term) & $\begin{array}{c}1.087^{*} \\
(2.45)\end{array}$ \\
\hline$N$ & 3854 \\
\hline$R^{2}$ & 0.099 \\
\hline Adjusted $R^{2}$ & 0.098 \\
\hline RMSE & 1.559 \\
\hline
\end{tabular}

$t$ statistics in parentheses

${ }^{*} p<0.05,{ }^{* *} p<0.01,{ }^{* * *} p<0.001$. 